LUKA VUKIĆ, Ph.D. ${ }^{1}$

E-mail: luka.vukic@pfst.hr

GIAMBATTISTA GUIDI, Ph.D. ${ }^{2}$

E-mail: giambattista.guidi@enea.it

TANJA POLETAN JUGOVIĆ, Ph.D. ${ }^{3}$

E-mail: poletan@pfri.hr

RENATO OBLAK, Ph.D. ${ }^{4}$

E-mail: renato.oblak@ri.ht.hr

${ }^{1}$ University of Split, Faculty of Maritime Studies

Ruđera Boškovića 37, 21000 Split, Croatia

2 ENEA (Italian National Agency for New Technologies,

Energy and Sustainable Economic Development)

Department of Energy Technologies and Renewable

Energy Sources

Via Anguillarese 301, 00123 Rome, Italy

${ }^{3}$ University of Rijeka, Faculty of Maritime Studies

Studentska 2, 51000 Rijeka, Croatia

${ }^{4}$ Adria Polymers d.o.o.

Poje 1, 51513 Omišalj, Croatia
Transport Economics Original Scientific Paper Submitted: 3 Sep. 2020 Accepted: 26 Mar. 2021

\title{
COMPARISON OF EXTERNAL COSTS OF DIESEL, LNG, AND ELECTRIC DRIVE ON A RO-RO FERRY ROUTE
}

\section{ABSTRACT}

Following the sustainable transport policy, environmental criteria are becoming a competitive factor within the maritime shipping industry. The use of greener fuels in internal combustion engines, including electric drive, is a measure that can reduce external costs of transport. Alternative fuels in maritime transport, benefits, and potential attainable savings have been examined on the Kamenari-Lepatane ro-ro ferry route in the Bay of Kotor located in Montenegro. The results indicate higher total fuel cost savings by switching to $L N G$ compared with electric power. However, the external costs of the latter are considerably lower, especially using renewable energy sources rather than fossil ones in the production process. The results obtained, relative to the magnitude and assumed complete internalization of external costs, justify the incentive to use the renewable sources as energy providers on the examined ro-ro ferry route. Environmental criteria should play a decisive role in assessing the overall benefit value, under the current trends and regulations of emissions reduction in maritime transport.

\section{KEYWORDS}

alternative fuels; Bay of Kotor; external costs; ro-ro ferry line; sustainable development.

\section{INTRODUCTION}

The impact of air pollution as a product of exhaust emissions on the environment has acquired special global attention [1]. Maritime transport is responsible for $80 \%$ of the volume of worldwide cargo trade [2] and is considered to be a more energy-efficient mode of transport [3, 4] compared with generated external costs of the predominated road modality [5]. However, the maritime transport mode, selected primarily for the large capacity, is burdened with the emissions as a result of the fuel combustion in marine engines and significantly contributes to the overall air pollution which has become a major threat for environment and human health [6]. Environmental protection initiatives from transport emissions of maritime transport are prevailing the international and European programs [7], indicating close correlation between emissions from the shipping industry and fuel consumption [8]. During the last decades, shipping was strongly dependent on marine diesel engines. The initiative of the IMO (International Maritime Organization) within the vessel emission regulations to decrease the negative impact of maritime transport on the environment has been manifested in $0.5 \%$ sulfur limit 
in the fuel oil combusted and the $\mathrm{NO}_{\mathrm{x}}$ Tier III requirements on technical improvements of diesel engines. The Energy Efficiency Design Index and Ship Energy Efficiency Management Plan were introduced having the aim of lowering ship related GHG emissions, mainly directed to the improvement of both the fuel oil and the engine quality characteristics. These measures proportionally contributed to the reduction of the undesirable emissions limiting the sulfur dioxide $\left(\mathrm{SO}_{2}\right)$, particulate matter $(\mathrm{PM})$, nitrogen oxides $\left(\mathrm{NO}_{\mathrm{x}}\right)$ carbon dioxide $\left(\mathrm{CO}_{2}\right)$, and other substances of exhaust emissions [9]. These chemical substances as a product of the fuel combustion in marine engines are characterized as detrimental to the environment and human health [10]. In 2011, the European Commission (EC) adopted the White Paper on transport prescribing the reduction obligation of $\mathrm{CO}_{2}$ emissions generated from maritime transport by $40 \%$ until 2050 compared to the 2005 levels and optionally, if possible even more, by 50\% [11]. This regulation was followed by two complementing international efforts to address greenhouse emissions, the Paris agreement as a global initiative from the United Nations Framework Convention on Climate Change (UNFCCC) to limit the increase of temperatures to $+1,5^{\circ} \mathrm{C}$ [12], and the 2030 Agenda for Sustainable Development, particularly the Sustainable Development Goal 13, to reduce the impacts of the climate change [13]. An initial IMO strategy was adopted in 2018 to reduce total annual greenhouse gas emissions from ships, which accounted for $2.2 \%$ of anthropogenic carbon dioxide emissions, by at least $50 \%$ by 2050 compared to the 2008 levels [2]. The strategic legislative framework of the European Union follows the global initiatives for climate change control and air pollution reduction from shipping [14]. Also, as of January 2018, large ships calling to ports inside the EU are required to report their verified annual emissions and other relevant information according to Regulation 2015/757, which was later amended by Delegated Regulation 2016/2071 [15].

The environmental damage caused by pollutants in the form of emissions can be expressed as a monetary value representing the external costs [16]. These costs are a measure of taxation or economic disincentive action having the aim to indicate the true costs of the utilization of transport modalities and stimulate changes in land use policy [17]. All the considered regulating legislative frameworks have the objective to tackle the negative transport implications. They principally aim to reduce the negative structural elements of traffic externalities [18], with air pollution as the principal segment [6], and they correlate with external costs [19]. The potential outcome of these interventions could result in a modal shift and decreased pollution [20]. Greater potential mobility, if realized by motorized transport modes, generates negative environmental impacts, such as fossil fuel consumption and greenhouse gas emissions (GHG) [21]. The White Paper indicated the internalization of external costs as the main tool for achieving sustainable development of the transport sector [11]. This is particularly important for the decision-makers in the transport logistic chain to estimate current and future external costs if internalized through policy instruments [19], in the process of service pricing [22]. The objective of the paper is to calculate the environmental external costs of ro-ro ferry transport on the Kamenari-Lepetane route situated in the Bay of Kotor in Montenegro. The research was performed by analyzing three different propulsion systems that utilize four selected fuel types and calculating the air emissions of individual fuel with a monetary valuation of the damage. Furthermore, the contribution was to endorse the usage of "greener" technologies against those gathered from anthropogenic sources and the incentive to use renewable sources as an energy provider, contributing to the current regulations in shipping and transport.

The remaining part of the paper is organized as follows: the review of relevant technical and environmental characteristics of three selected fuel types in marine engine combustion, i.e., diesel, liquefied natural gas (LNG), and electric propulsion, is presented in the second section, along with the analysis of the main research problem. Section 3 contains a detailed definition of the research objective, analysis building, and preparation of relevant data on the selected sample. Section 4 provides the results of the conducted research, which is followed by the discussion on the research findings. Finally, Section 5 comprises the main conclusions of the research with limitations and recommendations for further research.

\section{PROBLEM DESCRIPTION AND LITERATURE REVIEW}

\subsection{Problem and research subject description}

The paper intends to demonstrate the upper, lower, and average limits of the external cost, considering the use of three propulsion systems and 
four different fuel types, excluding the synergies between two types of propulsion as well as the hybrid technologies. The calculation of environmental external costs of the individual energy source type and the comparison of the compiled results is a central part of the paper. The premise of the complete internalization of the external costs was taken into calculation. Also, the costs of the propulsion systems retrofit have not been integrated into this research. Complementary to the examination of the benefits and cost savings of the fuel change, the isolated impacts of selected pollutants affecting human health and climate change are compared. Regarding the defined research problem and objective of the paper, the main research hypothesis was set to verify the following statement: the use of alternative fuel combustion sources compared to diesel fuel oil reduces the overall external costs on the selected ro-ro ferry route and proportionally lowers the negative impact on the environment and society. The data indicated in Figure 1 reflect the methodology of the conducted research. Data on input values, which were determined based on three research scenarios, were processed and interconnected with emission factors values to calculate specific and overall pollutant emissions. Based on the results received, the internalization principle was applied, including the valorization of emissions and comparison between scenarios.

The Bay of Kotor is a protected area characterized by significant marine species diversity and natural resources [23]. Decision-makers should integrate the preservation of the environment in the project projections and examine potential negative repercussions of transport activities on specific natural resources when planning the infrastructural projects in a particular area. The increase in energy consumption reciprocally enhances negative transport externalities but can also induce environmental degradation and decrease the quality of everyday living [24]. Construction of the bridge over the Bay of Kotor and preferring the road modality rather than maritime ro-ro ferry transport from the aspect of air emissions can devastate the environment and reduce biodiversity, valorized in the form of increased external costs of transport. Strategic planning of the future investments should follow the global and environmental transport trends of the modality change from road to alternative forms of transport, which contribute to lowering the overall external costs. The previous studies on the similar research subject were published by Nikolić and Nikolić [25] and Nikolić et al. [26], calculating the noise level of the village Kamenari as well as the noise risk to seafarers on one ferry operating on the Kamenari-Lepetane route. There is another study by Nikolić et al. [27], where authors calculated the exhaust emissions quantities from cruise vessels in the Bay of Kotor.

The following section represents a detailed overview of the research problem combined with the summary of relevant research, complementary to the individual activity. These activities include the review of the external costs of the diesel propulsion system, comprising two types of diesel fuel oil, Low Sulfur Marine Gas Oil (LS MGO) and Euro Diesel, external costs of an LNG propulsion system, and external costs of the electric propulsion system. The

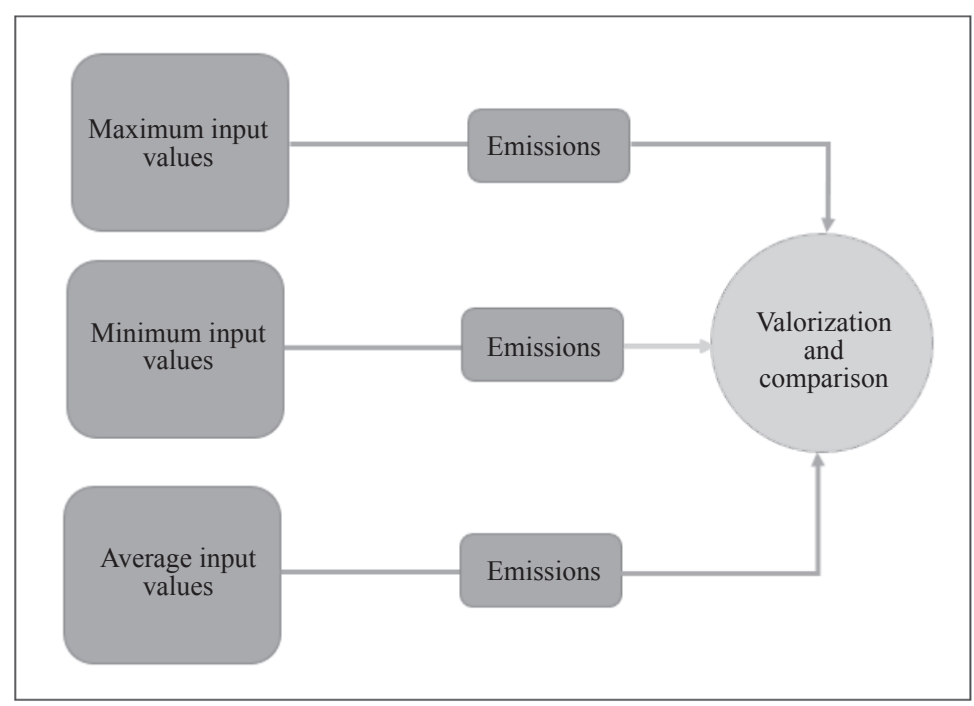

Figure 1-Flow chart of the research 
research culminates with a comparative analysis of individual emissions, valorized using the relevant methodology.

\subsection{External costs of the diesel propulsion system}

The first part of this research is based on the calculation of the marine engine air emissions costs, comprising two types of diesel fuel oil, LS MGO and Euro Diesel. The data obtained are used to determine the generated impact on society and the environment in the form of monetary unit values of emission pollutants, according to the most recent handbook of Van Essen et al. [28] on the external costs in transport and other relevant external sources. The used handbook is based on previous editions [29-31] comprising the revised, estimated unit values of pollutants, with the endeavor to internalize external costs. Ro-Ro ferry maritime route Kamenari-Lepetane is indispensable for the transport of vehicles and passengers, the benefit of which is reflected in avoiding the operations on the E65 road route around the Bay of Kotor. The most relevant research, having a similar research problem, was performed by Kalli et al. [32] who calculated air emissions from ships in the Gulf of Finland on a yearly basis. The research followed the calculation methodology of including the conversion of generated emissions into monetary values, based on different vessel types, where the largest share of total externalities was produced by $\mathrm{CO}_{2}$ emissions. The research findings support the hypothesis that the volume of overall externalities is mainly determined by the amount and the unit price of $\mathrm{CO}_{2}$.

\subsection{External costs of an LNG propulsion system}

The subsequent activity of the paper is the calculation of the environmental external costs using the hypothetical conversion of the ro-ro ferry diesel engine with the engine using LNG as fuel. The results should determine whether the use of LNG as fuel reduces the environmental external costs on the specific route, and the volume of external cost savings with the implementation of the LNG propulsion, according to the specific calculation. Despite the excessive use of the fossil fuels producing the environmental pollution in the form of climate change, natural gas was indicated as the cleaner energy resource to achieve the global emission reduction [33], showing particular promise as an alternative fuel [34]. The use of LNG, alternatively to the conventional fuel oils, reduces the emissions of $\mathrm{PM}$ and $\mathrm{SO}_{\mathrm{x}}$ by approximately $100 \%, \mathrm{NO}_{\mathrm{x}}$ by $85 \%$, and $\mathrm{CO}_{2}$ in the range from 20 to $25 \%$ [35], producing $92 \%$ lower emissions when compared to emission factors of heavy fuel oil (HFO) [36]. Besides the potential benefits of the LNG in maritime transport, various studies indicated high initial investment costs of the technology [37, 38]. The environmental dimension of the use of LNG on ferries has already attracted diverse research $[39,40]$. Livanos et al. [41] analyzed the techno-economic sustainability of four alternative propulsion plants running either on diesel or LNG fuels, on a typical ferry or Ro-Ro ship operating in a route passing the emission control area (ECA). Fokkema et al. [42] analyzed the economic perspective of investment in newly built vessels comparing the LNG dual-fuel engine propulsion with a conventional fuel engine while Hua et al. [10] examined two vessels with different propulsion, operating on HFO and LNG as fuels on the route across the Taiwan Strait. The latter research resulted with lower emissions of vessels powered by LNG. The study of the use of natural gas as an alternative to HFO and light fuel oil (LFO) on passenger ships in Greece was performed by Tzannatos and Nikitakos [9], calculating the reduction of air emissions and climate change impact expressed through external costs.

\subsection{External costs of an electric propulsion system}

The following section examines the hypothetical installation of electric power for the mentioned ro-ro ferries, implementing batteries as a viable solution to reduce emissions from the marine industry [43]. Having the intention to eliminate the excessive ship emissions while in port, vessels are encouraged to connect to the landside electricity supply [44], rather than providing power from the onboard auxiliary generators [45]. The use of the battery-operated electric motor ferry has become available with the transition to the green technology [46], with the objective of zero-emission technology creation. The charging process of the ship batteries is performed by the use of cold ironing [47]. However, as mentioned by Davarzani et al. [48], the sources of the produced electricity will determine the impact of electrification on the ship emissions and environment. It should also be specified that to 
accomplish the complete zero-emission and sustainability goals, the reproduced power necessary for cold ironing technology operation should emerge from renewable energy sources, which are cleaner when compared to the fossil ones. The use of batteries as propulsion in the maritime industry is most suitable for shorter routes with a charging installation situated onshore and providing enough power to perform the trip without additional charge [49]. There are several European ferries on routes equipped with a fully electric technology, like the ferry route between Lavik and Oppedal (Norway) operated by the first fully electric Li-ion battery-powered passenger and car ferry having the frequent battery charge and battery lifetime of ten years [50]. Another example is the passenger ferry between Solna Strand and Gamla Stan (Sweden) powered by Nickel-Metal-Hydride (Ni-MH) batteries, having the ability to reach 9 knots speed lasting an hour after ten minutes of charging [51]. Furthermore, in 2019, the e-ferry Ellen started its operation between the Danish ports of Fynshav and Soby, with a power capacity of $4.3 \mathrm{MWh}$ and being able to carry 30 vehicles and 200 passengers to distances up to 22 nautical miles between charges [52]. High investment costs of the infrastructure should be taken into consideration regarding the potential investments, which is also indicated by several authors [53-55].

\section{DATA PREPARATION AND MODEL CREATION}

The Kamenari-Lepetane route is operated all year round by six ro-ro ferries on a turnaround trip for the transport of vehicles and passengers. The sea distance between the two locations is approximately 900 meters or 0.49 nautical miles, with the time of departure scheduled every 15 minutes or as required, depending on the season period and market demand. The ro-ro ferry is the essential means of transport, enabling savings of approximately 20 $\mathrm{km}$ of single track and often congested road running

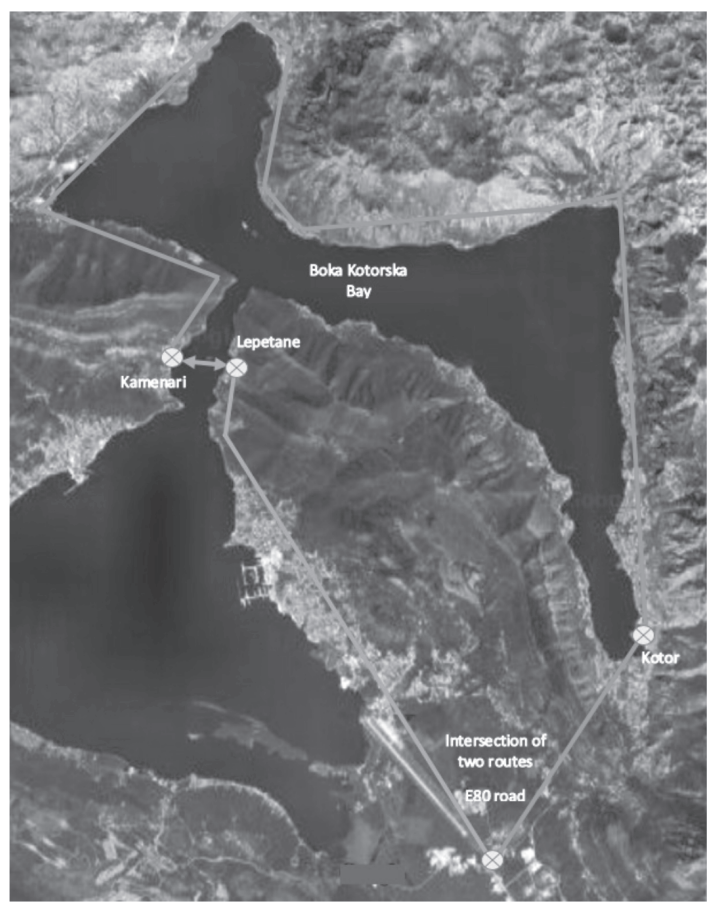

Figure 2 - Maritime and road connections in the Bay of Kotor

around the Bay of Kotor, shortening the path from Herceg Novi towards Budva, where the two routes are later connected by the road E80 (Figure 2). As for the strong dependence of the community on the roro ferry transport, the selected sample is significant for the research and analysis from the economic and socio-ecological standpoint, particularly when UNESCO expressed disapproval of the construction of a bridge across the two shores of the Bay of Kotor [56]. The maximum period of the full service combining the waiting time, operations of embarkation and disembarkation, and transport is about 15 minutes [57].

The frequency of arrivals and departures has been taken and estimated from summer and winter timetables, and calculated to the yearly levels, due to lack of the official and relevant data. As the model propositions were to calculate the upper, lower, and average external cost limits, the frequency of voyages between Kamenari and Lepetane was calculated based on maximum, minimum, and average

Table 1 - Annual number of voyages and navigation stages on the Kamenari-Lepetane maritime route at maximum, minimum, and average levels

\begin{tabular}{||l|c|c|c|c||}
\hline \multicolumn{1}{|c|}{ Frequency } & $\begin{array}{c}\text { Number of } \\
\text { voyages (yearly) }\end{array}$ & $\begin{array}{c}\text { The overall time of } \\
\text { voyages }[\mathrm{h}]\end{array}$ & $\begin{array}{c}\text { Operation - } \\
\text { navigation }(2 / 3)[\mathrm{h}]\end{array}$ & $\begin{array}{c}\text { Operation - embarkation and } \\
\text { disembarkation }(1 / 3)[\mathrm{h}]\end{array}$ \\
\hline \hline Maximum frequency & 83,772 & 20,943 & 13,962 & 6,981 \\
\hline Minimum frequency & 33,516 & 8,379 & 5,586 & 2,793 \\
\hline Average frequency & 58,644 & 14,661 & 9,774 & 4,887 \\
\hline \hline
\end{tabular}

Source: [57] (assessment based on the available timetables) 
levels of voyages. Table 1 provides an overview of the yearly number of voyages multiplied by the time of the voyage (15 minutes). The overall annual voyage time was multiplied and calculated proportionally for the individual phase of the voyage. Thereby, $2 / 3$ of overall voyage time was allocated to the navigational part (10 minutes), while the remaining part of $1 / 3$ to the operations of embarkation and disembarkation (5 minutes).

These ro-ro ferries are driven by the diesel propulsion system. Two of the six ro-ro ferries are equipped with two "Cummins" KTA 19-M3 propulsion systems having the power of $2 \times 447 \mathrm{KW}$ and $1,800 \mathrm{rpm}$. The other four older ro-ro ferries are powered by two "Cummins" KTA 19 type propulsion systems with the power of $2 \times 317 \mathrm{KW}$ and $1,800 \mathrm{rpm}$ [57]. The total ro-ro ferries engine power was calculated as an average value, combining the engine power of six ro-ro ferries (four old ones and two newer), resulting in the average engine power of $2 \times 360.3 \mathrm{~kW}$, and having the premise of all the ro-ro ferries in service. Usually, there are three operation modes at sea, which are in correlation with fuel consumption. For the purpose of this research, the load factors (LF) were determined only for two operation modes of a full voyage. These phases included the maximal LF (100\%) for the transit mode of the service, achieving the full engine rotational speed $(1,800 \mathrm{rpm})$, while the LF for hoteling mode was set proportionally to the reported engine rotational speed (700 rpm). Thus, the latter was calculated as a percentage (38.89\%) of the maximum level. Load factor levels were based on actual readings during the voyage and the feedback of the masters. It should be mentioned that this exemption could not have influenced the final results. All the presented values in this research were rounded to two decimal places, while the whole number values were used in the calculation. The average engine power and load factors for diverse operations, which were taken into calculation, are shown in Table 2.

The engine consumption level was taken according to the manufacturer's specifications for both engine types and converted to the average consumption, comprising all six ro-ro ferries consumption rates in service. As for the shortage of specific consumption (SFOC) data for engine power $447 \mathrm{~kW}$, the $448 \mathrm{~kW}$ engine power data was considered. Table 3 shows the engine power specifications along with SFOC and average SFOC for six ro-ro ferries in service.

After preparing the voyage specifications data and engine characteristics, the emission factors (EF) and unit prices of main pollutants are presented. The EF are provided separately for the ro-ro ferry using four diverse fuel types to determine possible savings by using the alternative fuel combustion system and fuel type, characterized as the more environmentally acceptable from the socio-ecological criteria. Four fuel types were taken into calculation as follows: Euro Diesel having $0.001 \%$ of sulfur content, LS MGO with $0.1 \%$ of sulfur content and Tier II engine emission standard, LNG, and electric power. When calculating the external cost of maritime transport, the main source of damage is mainly related to emissions, as congestion and accidents rarely occur, and are negligible for the overall research. The four main categories of pollutants examined in this research are namely $\mathrm{CO}_{2}, \mathrm{SO}_{2}, \mathrm{NO}_{\mathrm{x}}$, particulate matter with 10 micrometers or less in diameter (PM10), and particulate matter with 2.5

Table 2 - Average engine power, load factors, and duration of the two stages of operation

\begin{tabular}{||l|c|c||}
\hline & Operation - navigation & $\begin{array}{c}\text { Operation - } \\
\text { embarkation/disembarkation }\end{array}$ \\
\hline \hline Average engine power & $2 \times 360.3 \mathrm{~kW}^{*}$ & $2 \times 140.12 \mathrm{~kW}^{*}$ \\
\hline Load factor & $100 \%$ & $38.89 \%$ \\
\hline Time & 10 minutes & 5 minutes \\
\hline
\end{tabular}

*two engines

Table 3 - Average SFOC for six examined ro-ro ferries according to the engine characteristics

\begin{tabular}{||c|c|c||}
\hline Engine power & SFOC & $\begin{array}{c}\text { Average SFOC } \\
{[(4 \times 209 \mathrm{~g} / \mathrm{kWh})+(2 \times 207 \mathrm{~g} / \mathrm{kWh})] / 6}\end{array}$ \\
\hline \hline $317 \mathrm{~kW}$ & $209 \mathrm{~g} / \mathrm{kWh}$ & $208.33 \mathrm{~g} / \mathrm{kWh}$ \\
\hline $448 \mathrm{~kW}$ & $207 \mathrm{~g} / \mathrm{kWh}$ & \\
\hline
\end{tabular}

Source: [58] 
Vukić L, et al. Comparison of External Costs of Diesel, LNG, and Electric Drive on a Ro-Ro Ferry Route

Table 4-Pollutant emission factors of the examined fuel types

\begin{tabular}{||c|c|c|c|c||}
\hline Fuel (EF in g/kg) & $\mathrm{PM}_{10} / \mathrm{PM}_{2.5}$ & $\mathrm{NO}_{\mathrm{x}}$ & $\mathrm{SO}_{2}$ & $\mathrm{CO}_{2}$ \\
\hline \hline Euro Diesel Euro V $(0.001 \% \mathrm{~S})$ & $0.203 / 0.192$ & $36.66^{*}$ & 0.015 & 3,170 \\
\hline Fuel (EF in g/kWh) & $\mathrm{PM}_{10} / \mathrm{PM}_{2.5}{ }^{* *}$ & $\mathrm{NOx}$ & $\mathrm{SO} 2$ & $\mathrm{CO} 2$ \\
\hline LS MGO (0.1\% S), Tier II & $0.12 / 0.12$ & 10.4 & 1.13 & 757 \\
LNG & $0.00156 / 0.00156$ & 1.56 & 0.00678 & 734.3 \\
Electric & $0.022 / 0.022$ & 0.46 & 0.27 & 490 \\
\hline
\end{tabular}

*calculated value, Tier II, $2100 \mathrm{o} / \mathrm{min}$, EF $7.7 \mathrm{~g} / \mathrm{kWh}$ NOx, SFOC $210 \mathrm{~g} / \mathrm{kWh}$

**PM10/PM2.5 ratio in Adriatic 1

Source: [59-62]

Table 5 - Air pollution costs of the main pollutants in maritime traffic $(\epsilon / t)$

\begin{tabular}{||c|c|c|c|c|c||}
\hline & $\mathrm{CO}_{2}$ & $\mathrm{SO}_{2}$ & $\mathrm{NO}_{\mathrm{x}}$ & $\mathrm{PM}_{2.5}$ & $\mathrm{PM}_{10}$ \\
\hline \hline $\begin{array}{c}\text { Ro-Ro } \\
\text { ferry }\end{array}$ & 100 & 9,200 & 3,000 & 24,600 & 14,000 \\
\hline
\end{tabular}

Source: [28]

micrometers or less in diameter (PM2.5). Table 4 provides EF for four fuel types. Emission factors for LS MGO and LNG combustion and electric power were expressed as WTW (well-to-wheel) emissions in $\mathrm{g} / \mathrm{kWh}$ and taken from the sheet data of CE Delft [59]. As the EF for Euro Diesel was not available, it was taken from the external source [60] and expressed in $\mathrm{g} / \mathrm{kg}$. The value of the PM2.5 emission factor was taken from the research of Viana et al. [61], considering the PM10/PM2.5 emission factor ratio of 1 at the LS MGO, LNG combustion, and the electric production procedures in the area of Adriatic.

The valorization of emissions and the climate change unit values, expressed as $\mathrm{CO}_{2}$ equivalent emission due to a small and insignificant share of all other greenhouse gases, was conducted by applying air pollution costs values. The congestion and accident costs were excluded from the research. Air pollution costs of the main pollutants in maritime traffic are shown in Table 5.

The model combines the variables of fuel consumed, emission factors, and unit prices of pollutants to calculate and compare the external costs for three different fuel systems on ro-ro ferries concerning the maritime route Kamenari-Lepetane.

\section{RESEARCH RESULTS}

Results of the external costs calculation on the route Kamenari-Lepetane by ferry transport using four different types of fuel are presented in the following tables. As for the diverse measurement unit calculation $(\mathrm{g} / \mathrm{kg}$ and $\mathrm{g} / \mathrm{kWh})$, the data were divided and processed into several phases. Initially, the overall generated power expressed in $\mathrm{kWh}$ and overall fuel consumption (in $\mathrm{kg}$ ) of ro-ro ferries were calculated for each scenario (Table 6).

Furthermore, the generated results were multiplied by the emission factor of each pollutant, resulting in total emissions generated by ro-ro ferries using different fuel (Table 7).

Table 6 - Overall generated energy and fuel consumption of ro-ro ferries on the Kamenari-Lepetane route

\begin{tabular}{|c|c|c|c|}
\hline \multirow{2}{*}{ Kamenari-Lepetane ro-ro ferry } & \multicolumn{3}{|c|}{$2 \times$ engine power $[\mathrm{kW}] * \times$ time $[\mathrm{h}]=$ Energy $[\mathrm{kWh}]$} \\
\hline & MAXIMUM** & MINIMUM ${ }^{* * *}$ & AVERAGE**** \\
\hline 2/3 (10 $\mathrm{min})$ voyage, $\mathrm{LF} 100 \%$ & $10,061,017.2$ & $4,025,271.6$ & $7,043,144.40$ \\
\hline $1 / 3(5 \mathrm{~min})$ embarkation/disembarkation operations, LF $38.89 \%$ & $1,956,308.90$ & $782,691.7$ & $1,369,500.3$ \\
\hline OVERALL ENERGY [kWh] & $12,017,326.10$ & $4,807,963.3$ & $8,412,644.7$ \\
\hline \multicolumn{4}{|c|}{ ENERGY $[\mathrm{kWh}] \times$ average SFOC $[\mathrm{g} / \mathrm{kWh}] / 1000=$ FUEL $[\mathrm{kg}]$} \\
\hline $2 / 3(10 \mathrm{~min})$ voyage, $\mathrm{LF} 100 \%$ & $2,096,045,250$ & $838,598,250$ & $1,467,321,750$ \\
\hline 1/3 (5 min) embarkation/disembarkation operations, LF $38.89 \%$ & $407,564,354.2$ & $163,060,770.8$ & $285,312,562.5$ \\
\hline OVERALL FUEL [kg] & $2,503,609.6$ & $1,001,659.02$ & $1,752,634.3$ \\
\hline
\end{tabular}

*average engine power of six ro-ro ferries in exploitation, two engines

**distance $0.49 \mathrm{M}$, max. speed 8-10 kn, time 20,943 h (voyage time $15 \mathrm{~min}$ ), no. of voyages 83,772

***distance $0.49 \mathrm{M}$, max. speed $8-10 \mathrm{kn}$, time 8,379 $\mathrm{h}$ (voyage time $15 \mathrm{~min}$ ), no. of voyages 33,516

$* * * *$ distance $0.49 \mathrm{M}$, max. speed 8-10 kn, time 14,661 h (voyage time $15 \mathrm{~min}$ ), no. of voyages 58,644 
Vukić L, et al. Comparison of External Costs of Diesel, LNG, and Electric Drive on a Ro-Ro Ferry Route

\begin{tabular}{|c|c|c|c|c|c|c|c|c|}
\hline 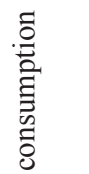 & $\widehat{a}$ & 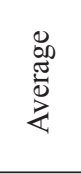 & 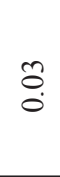 & \begin{tabular}{l} 
â \\
\multirow{b}{0}{}
\end{tabular} & ֻొ & $\stackrel{+}{m}$ & $\begin{array}{l}n \\
\infty \\
n \\
n \\
n \\
n\end{array}$ & 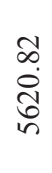 \\
\hline 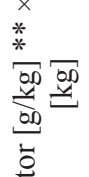 & $\begin{array}{l}\overline{8} \\
\dot{0} \\
\overline{0} \\
\stackrel{\tilde{u}}{0} \\
\ddot{0}\end{array}$ & $\begin{array}{l}\text { 䒠 } \\
\text { 具 }\end{array}$ & $\stackrel{\text { Oे }}{\circ}$ & 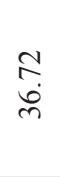 & ণ্ & $\frac{9}{0}$ & $\begin{array}{l}\stackrel{2}{n} \\
\stackrel{n}{n} \\
\end{array}$ & $\underset{\text { ते }}{\stackrel{\vec{\sim}}{\pi}}$ \\
\hline 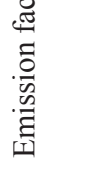 & 壱 & 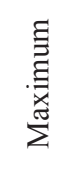 & $\stackrel{t}{0}$ & $\frac{\infty}{\stackrel{\alpha}{\sigma}}$ & $\bar{n}$ & $\stackrel{\infty}{+}$ & 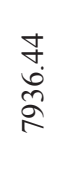 & $\begin{array}{l}\text { ते } \\
\text { ते } \\
\text { ठे }\end{array}$ \\
\hline \multirow{9}{*}{ 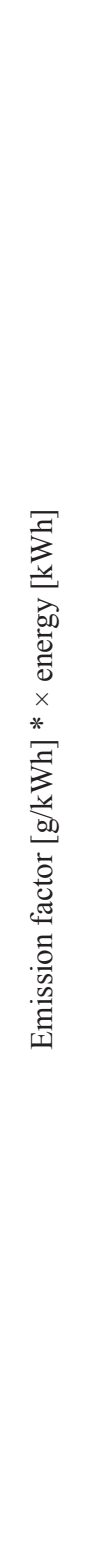 } & \multirow{3}{*}{ 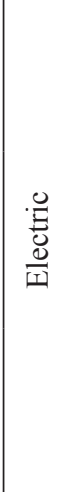 } & 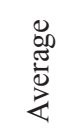 & $\widehat{\widehat{i}}$ & $\begin{array}{l}\hat{\infty} \\
\infty \\
\end{array}$ & $\frac{\overrightarrow{0}}{0}$ & $\frac{a}{0}$ & 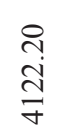 & $\begin{array}{l}\vec{\nabla} \\
\infty \\
\stackrel{0}{\sigma} \\
\vec{\sigma}\end{array}$ \\
\hline & & 章 & 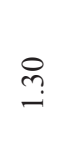 & $\overrightarrow{\widetilde{N}}$ & $=$ & $=$ & $\begin{array}{l}\stackrel{2}{a} \\
\hat{n} \\
\hat{n}\end{array}$ & $\begin{array}{l}\text { ర్ర } \\
\text { ते } \\
\text { ते }\end{array}$ \\
\hline & & 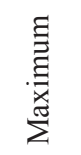 & $\underset{j}{\stackrel{J}{n}}$ & $\hat{n}$ & ֻి & ֻ̊ & $\begin{array}{l}\stackrel{a}{+} \\
\infty \\
\infty \\
\infty \\
\infty \\
i n\end{array}$ & $\begin{array}{l}\stackrel{2}{\hat{0}} \\
\stackrel{2}{\infty} \\
i\end{array}$ \\
\hline & \multirow{3}{*}{ 苔 } & 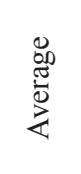 & $\stackrel{0}{\circ}$ & $\stackrel{\sim}{\stackrel{\sim}{m}}$ & $\stackrel{\square}{\circ}$ & $\stackrel{0}{\circ}$ & 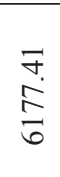 & $\begin{array}{l}\bar{\sigma} \\
8 \\
\stackrel{0}{6}\end{array}$ \\
\hline & & 声 & $\stackrel{\tilde{o}}{0}$ & in & $\stackrel{0}{\circ}$ & $\ddot{\circ}$ & 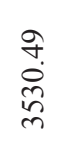 & $\begin{array}{l}\text { d } \\
\infty \\
\infty \\
\tilde{n} \\
n\end{array}$ \\
\hline & & 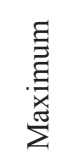 & $\stackrel{\infty}{\stackrel{0}{0}}$ & $\begin{array}{l}\stackrel{n}{n} \\
\infty \\
-1\end{array}$ & $\stackrel{\text { ô. }}{0}$ & $\stackrel{\leftrightarrow}{0}$ & $\begin{array}{l}\underset{\sim}{\sim} \\
\stackrel{+}{ \pm} \\
\infty \\
\infty\end{array}$ & 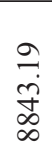 \\
\hline & \multirow{3}{*}{ 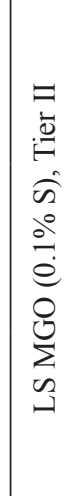 } & 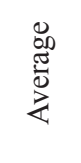 & $\bar{n}$ & $\underset{\infty}{\stackrel{g}{\dot{\infty}}}$ & $\stackrel{\sigma}{-}$ & $\stackrel{\vec{\sigma}}{-}$ & $\begin{array}{l}\hat{n} \\
0 \\
0 \\
0 \\
0\end{array}$ & $\begin{array}{l}\text { ले } \\
\text { tैं }\end{array}$ \\
\hline & & 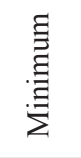 & $\underset{f}{f}$ & $\begin{array}{l}8 \\
\text { in }\end{array}$ & $\begin{array}{l}\infty \\
\stackrel{n}{0}\end{array}$ & $\begin{array}{l}\infty \\
\stackrel{n}{0}\end{array}$ & $\begin{array}{l}\hat{0} \\
\hat{0} \\
\hat{\sigma} \\
0\end{array}$ & 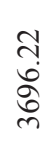 \\
\hline & & 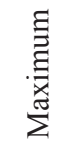 & $\begin{array}{l}\infty \\
\stackrel{\infty}{n} \\
m\end{array}$ & $\begin{array}{l}\stackrel{\infty}{\stackrel{+}{ \pm}} \\
\stackrel{+}{ \pm}\end{array}$ & $\stackrel{f}{\underset{-}{*}}$ & $\stackrel{\forall}{\stackrel{J}{*}}$ & $\begin{array}{l}\stackrel{7}{1} \\
\text { مे }\end{array}$ & $\begin{array}{l}\stackrel{0}{ } \\
\infty \\
\approx \\
\sigma\end{array}$ \\
\hline & & 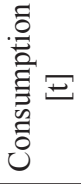 & $0^{N}$ & $\varrho^{*}$ & $\sum_{i}^{\infty}$ & $\sum_{i=1}^{n}$ & $8^{N}$ & 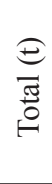 \\
\hline
\end{tabular}

\begin{tabular}{|c|c|c|c|c|c|c|c|c|}
\hline \multirow{12}{*}{ 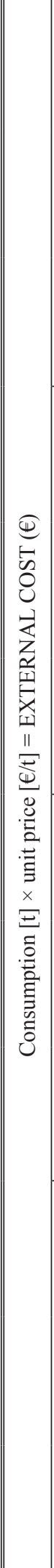 } & \multirow{3}{*}{ 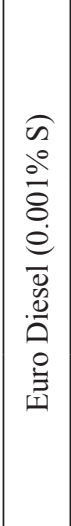 } & 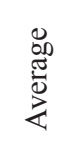 & 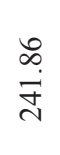 & $\begin{array}{l}\mathfrak{N} \\
\dot{d} \\
\stackrel{n}{\alpha} \\
\text { a }\end{array}$ & $\begin{array}{l}\hat{\partial} \\
\hat{े} \\
\stackrel{\infty}{ } \\
\hat{\sigma}\end{array}$ & 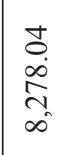 & $\begin{array}{l}\hat{0} \\
\hat{0} \\
n \\
\hat{n} \\
n\end{array}$ & $\begin{array}{l}\hat{0} \\
\dot{y} \\
0 \\
0 \\
0\end{array}$ \\
\hline & & $\begin{array}{l}\text { 稟 } \\
\text { 具 }\end{array}$ & $\begin{array}{l}\tilde{n} \\
\infty \\
\stackrel{n}{=}\end{array}$ & $\begin{array}{l}0 \\
+ \\
i \\
0 \\
0 \\
0 \\
=\end{array}$ & $\begin{array}{l}\vec{R} \\
0 \\
0 \\
0 \\
i\end{array}$ & $\begin{array}{l}\dot{t} \\
\dot{\sigma} \\
\stackrel{\tilde{r}}{+} \\
\dot{f}\end{array}$ & 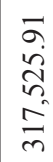 & $\begin{array}{l}+ \\
\stackrel{+}{+} \\
\dot{q} \\
\dot{n} \\
\vartheta\end{array}$ \\
\hline & & 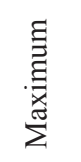 & $\begin{array}{l}0 \\
\text { in } \\
\text { pr }\end{array}$ & 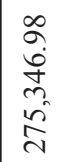 & 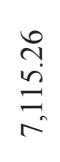 & 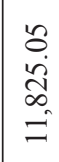 & $\begin{array}{l}\text { N } \\
\text { Jj } \\
\text { ஸे } \\
2\end{array}$ & 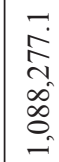 \\
\hline & \multirow{3}{*}{ 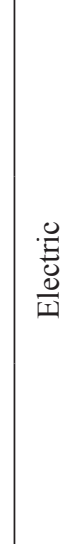 } & 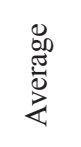 & $\begin{array}{l}\overrightarrow{0} \\
\hat{a} \\
\text { o } \\
\stackrel{1}{0}\end{array}$ & $\begin{array}{l}n \\
f \\
a \\
0 \\
0 \\
= \\
=\end{array}$ & $\begin{array}{l}a \\
\hat{a} \\
\hat{a} \\
i \\
i\end{array}$ & $\begin{array}{l}\sigma \\
\hat{i} \\
\tilde{n} \\
n \\
\sim\end{array}$ & 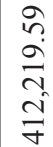 & $\begin{array}{l}\vec{g} \\
\dot{\infty} \\
\vec{g} \\
\vec{g}\end{array}$ \\
\hline & & $\begin{array}{l}\text { 音 } \\
\text { 兽 }\end{array}$ & \begin{tabular}{l}
$\infty$ \\
$\stackrel{1}{1}$ \\
\multirow{2}{0}{} \\
$=$
\end{tabular} & $\begin{array}{l}\hat{\partial} \\
\dot{j} \\
\hat{b} \\
0\end{array}$ & $\begin{array}{l}n \\
\infty \\
0 \\
\infty \\
\infty \\
\stackrel{\infty}{0} \\
-\end{array}$ & $\begin{array}{l}1 \\
\hat{a} \\
\text { ì } \\
\text {. } \\
\text { in }\end{array}$ & 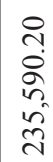 & 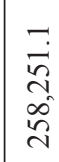 \\
\hline & & 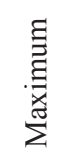 & $\begin{array}{l}\dot{J} \\
\dot{\vec{n}} \\
\infty \\
\partial \hat{\nu}\end{array}$ & $\begin{array}{l}\bar{\sigma} \\
\hat{\infty} \\
0 \\
\hat{n} \\
0\end{array}$ & 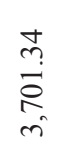 & $\begin{array}{l}\infty \\
\hat{n} \\
\hat{\beta} \\
\hat{n} \\
0\end{array}$ & $\begin{array}{l}\infty \\
\circ \\
\infty \\
\infty \\
\infty \\
\infty \\
\infty \\
n\end{array}$ & 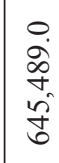 \\
\hline & \multirow{3}{*}{$\begin{array}{l}0 \\
\vdots \\
Z\end{array}$} & 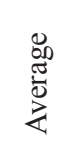 & $\begin{array}{l}\stackrel{n}{\sim} \\
\underset{\sim}{\sim}\end{array}$ & $\begin{array}{l}\infty \\
\vec{n} \\
\text { n. } \\
\text { m. }\end{array}$ & $\begin{array}{l}m \\
\ddot{\infty} \\
\infty\end{array}$ & $\begin{array}{l} \pm \\
\text { i } \\
\text { तె }\end{array}$ & $\begin{array}{l}8 \\
0 \\
0 \\
\hat{j} \\
\hat{i} \\
0\end{array}$ & $\begin{array}{l}\dot{0} \\
\stackrel{\sim}{二} \\
\infty \\
0 \\
0\end{array}$ \\
\hline & & 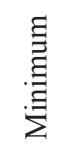 & $\begin{array}{l}\text { ̊े } \\
\text { ळे }\end{array}$ & 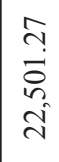 & $\begin{array}{l}\overrightarrow{0} \\
\ddot{0} \\
0\end{array}$ & $\begin{array}{l}\vec{n} \\
\dot{\infty} \\
\infty \\
\end{array}$ & $\begin{array}{l}n \\
\hat{0} \\
\infty \\
0 \\
\approx \\
n \\
n\end{array}$ & $\begin{array}{l}+ \\
\stackrel{0}{0} \\
\hat{0} \\
\stackrel{n}{0}\end{array}$ \\
\hline & & 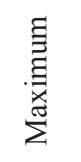 & \begin{tabular}{l} 
ڤे \\
\multirow{2}{*}{}
\end{tabular} & 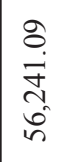 & $\begin{array}{l}\stackrel{0}{1} \\
\text { di }\end{array}$ & $\stackrel{\infty}{\frac{\infty}{b}}$ & 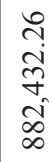 & 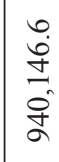 \\
\hline & \multirow{3}{*}{ 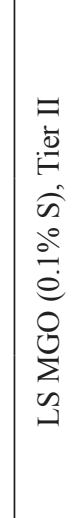 } & 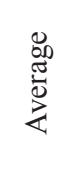 & \begin{tabular}{l}
$n$ \\
$\infty$ \\
$\hat{n}$ \\
\multirow{n}{\infty}{} \\
$\infty$ \\
$\infty$
\end{tabular} & 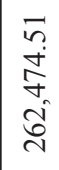 & 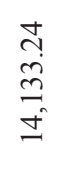 & $\begin{array}{l}n \\
\dot{d} \\
\tilde{D} \\
\dot{d}\end{array}$ & $\begin{array}{l}\text { ते } \\
\text { م) } \\
0 \\
0 \\
0 \\
0\end{array}$ & 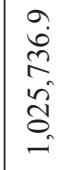 \\
\hline & & 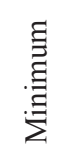 & 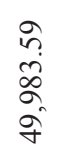 & \begin{tabular}{l}
$n$ \\
\multirow{2}{*}{} \\
$\infty$ \\
8 \\
8 \\
0 \\
0 \\
$n$
\end{tabular} & $\begin{array}{l}\underset{\infty}{\infty} \\
\stackrel{0}{\stackrel{0}{0}} \\
\infty\end{array}$ & $\begin{array}{l}= \\
\approx \\
\stackrel{\Xi}{\Xi}\end{array}$ & 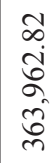 & 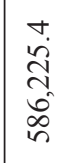 \\
\hline & & 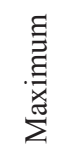 & 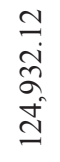 & $\begin{array}{l}\hat{n} \\
\dot{o} \\
a \\
+ \\
\text { ñ }\end{array}$ & $\begin{array}{l}= \\
\dot{\infty} \\
\overrightarrow{0} \\
\overrightarrow{0}\end{array}$ & \begin{tabular}{l}
$n$ \\
$\stackrel{n}{n}$ \\
\multirow{f}{*}{} \\
$\stackrel{n}{n}$
\end{tabular} & 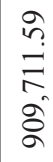 & 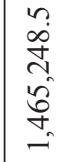 \\
\hline & & 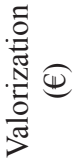 & $\overbrace{}^{N}$ & $\stackrel{O}{z}^{*}$ & $\sum_{i}^{\infty}$ & $\sum_{i}^{n}$ & $\mathcal{O}^{0}$ & 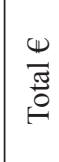 \\
\hline
\end{tabular}


Vukić L, et al. Comparison of External Costs of Diesel, LNG, and Electric Drive on a Ro-Ro Ferry Route

Table 9 - Overview of the share of CO2 emissions in comparison with the health harmful related emissions of the examined alternatives

\begin{tabular}{||c|c|c|c|c||}
\hline Emissions & $\begin{array}{c}\text { LS MGO } \\
(0.1 \% \mathrm{~S}), \text { Tier II }\end{array}$ & LNG & Electric & $\begin{array}{c}\text { Euro Diesel } \\
(0.001 \% \mathrm{~S})\end{array}$ \\
\hline \hline $\mathrm{SO}_{2}+\mathrm{NO}_{\mathrm{x}}+\mathrm{PM}_{10}+\mathrm{PM}_{2.5}$ & $37.91 \%$ & $6.14 \%$ & $8.77 \%$ & $27.07 \%$ \\
\hline $\mathrm{CO}_{2}$ & $62.09 \%$ & $93.86 \%$ & $91.23 \%$ & $72.93 \%$ \\
\hline TOTAL & $100 \%$ & $100 \%$ & $100 \%$ & $100 \%$ \\
\hline
\end{tabular}

Finally, as the main objective of the research was to calculate the monetary values of external costs and comparison between alternative fuels, the valorization of emissions (expressed in tons) was performed using the air pollution unit values and the amounts of the emitted pollutants. The results of the external cost valorization are shown in Table 8.

The results show considerable cost effects in the examined fuel change of all three alternatives. Already by switching fuel from LS MGO to Euro Diesel, a significant reduction of the external cost values is evident, providing the potential yearly average cost savings of $€ 263,896.3$, as the most relevant and objective cost assessment level. The analysis of other alternatives indicated external cost savings of fuel switch from LS MGO to LNG of $€ 367,593.9$, and $€ 573,866.9$ when shifting the fuel from LS MGO to electric propulsion. Also, when performing the fuel switch from Euro Diesel to LNG, indicated as the cleaner and more environmentally friendly fuel, the shipping company cost savings reaches $€ 103,697.7$ of the total external costs, considering the premise of complete internalization of external costs. The electric power showed the most significant improvements in the reduction of the overall quantities of the examined pollutants and monetary values of external costs, namely by $€ 206,272.9$ in comparison with LNG and by $€ 309,970.6$ related to Euro Diesel. By examining all three scenarios (maximum, minimum, and average values) provided in Tables 7 and 8, depending on the fuel selection, it can be concluded that the share of $\mathrm{CO}_{2}$ emissions varies from $62.09 \%$ to $93.86 \%$ out of total emissions. The share of $\mathrm{CO}_{2}$ emissions directly determines the share of remaining emissions, which are primarily health related. The share of $\mathrm{CO}_{2}$ emissions, in comparison with the harmful health-related emissions of the selected alternatives, is shown in Table 9.

The results generated indicate the reduction of the health harmful related emissions on the Kamenari-Lepetane maritime route by the fuel change from the conventional fuels (LS MGO and
Euro Diesel) to alternative ones (LNG and electric). A high share of $\mathrm{CO}_{2}$ emissions indicated in Table 9 is a consequence of chemical composition and process in the combustion of fossil fuels and electric power production, including batteries. It confirms the utmost importance of $\mathrm{CO}_{2}$ emissions, which based on individual component analysis, remains the leading combustion by-product. The emission factor values from Table 4 reflect the predominance of $\mathrm{CO}_{2}$ emissions. However, almost reciprocally, an increase in the share of climate change emissions, expressed as a $\mathrm{CO}_{2}$ equivalent emission, is also recorded.

\section{DISCUSSION}

The results gathered from the conducted research were presented as the average values of the calculated emissions, an approach which was taken as the most representative for this research. By all examined parameters in the form of exhaust emissions substances, the use of electric power on ro-ro ferries was indicated as ecologically more acceptable in all scenarios. However, neither the implementation nor the retrofit or potential maintenance of the propulsion system was taken into calculation. Regarding the emissions generated, the $\mathrm{SO}_{2}$ emissions of the LNG fuel combustion were found twice as high as in the Euro Diesel combustion, but the amounts of the emitted $\mathrm{NO}_{\mathrm{x}}, \mathrm{PM} 10$, and PM2.5 were 4 to more than 27 times lower. As expected, the highest emissions generated were calculated with the use of LS MGO on ro-ro ferries, which expressed in the monetary value of external costs extends to over $1,025,736.9 € / y$ in the average scenario on the examined maritime route. This amount becomes the responsibility of the shipping company in the conditions of complete external cost internalization. Proportionally, this would surely influence the expense of the end-users in the shape of the increased transport price. Relations of the generated results, presented as valorized climate change emissions and health harmful related emissions, clearly indicate the advantages of using LNG and electric 
power, but also the use of Euro Diesel fuel, having a lower share of sulfur content compared to LS MGO. The benefits are significant and invaluable, visible in a lower share of the health harmful related emissions of LNG, electric power, and Euro Diesel $\left(\mathrm{SO}_{2}+\mathrm{NO}_{\mathrm{x}}+\mathrm{PM} 10+\mathrm{PM} 2.5\right)$ varying from $6.14 \%$ to $37.91 \%$, compared to LS MGO (Table 9) considering the value of the human life.

The results of this research undoubtedly follow and support current trends in the transport sector considering environmental protection, especially the reduction of emissions in shipping. Following the provided calculation and considering the guidelines of the internalization of external costs, the external costs of transport are empirically tested and calculated, indicating the obligation of tackling the emissions by performing the fuel change. There is a strong need to create a model of external costs calculation to numerically express the negative externalities, which would surely provide significant support to interested stakeholders in the logistic chain of the service provision. Finally, the results and conclusions were used to conduct the hypothesis testing and, based on the generated results of the research, the hypothesis was accepted, indicating the reduced impact of the ro-ro ferry transport on the sustainable development by the use of alternative fuels.

The perspective of utilizing environmentally less harmful propulsion in maritime transport and transport in general should not be based only on the selection of the fuel type of the ultimate consumer, the level of pollution, and its generated external costs, but primarily on the method of obtaining the energy consumed. Tackling the negative externalities at the endpoint of the final consumer can be characterized as a futile act, since detrimental actions towards the environment continue at the source. The most appropriate example is the process of obtaining electricity from a fossil fuel power station. Renewable energy sources as solar, wind, geothermal, or wave energy, as well as the development of the commercial use of hydrogen as a fuel in transport are the alternatives that would contribute to the systematic reduction and elimination of external costs of transport in the overall energy production and consumption chain nominated as WTW external costs (well-to-wheel). All specified solutions aim at the preservation of the environment and human health, so its implementation and utilization are more preferable to the construction of the bridge over the Bay of Kotor. The realization of the latter would contribute to the increase of emissions (besides aesthetical distortion) in the unique natural resource for which the obligation of protection exists.

In addition to the primary objective of the research, there was a need to compare potential cost effects of the fuel change on ro-ro ferries operating on the Kamenari-Lepetane maritime route concerning the fuel costs. The calculation of the fuel change costs during the switch from Euro Diesel to alternative fuels on the examined ro-ro ferries is shown in Table 10. The energy prices expressed were intended for households in Montenegro [63]. Montenegro has no access to gas [64]. The LNG unit price of $0.0436 € / \mathrm{kWh}$ was formed as an average value of actual prices in the surrounding area (Croatia, Serbia, and North Macedonia) [65]. The real absolute fuel cost is $17.5 \%$ lower (with the deduction of VAT), but the savings percentage is equal.

The results indicate the benefits of the LNG fuel and electric power compared to Euro Diesel in the fuel price, but also the cost savings of potentially internalized external costs on the Kamenari-Lepetane ro-ro ferry route. With the use of alternative fuels, the overall realized cost savings differ from 1,655,993.8 $€ / y$ concerning the change from Euro Diesel to electric propulsion, to $1,533,847.3 € / y$ with the switch to

Table 10 - Calculation of cost savings in fuel and external costs categories with the fuel change from Euro Diesel to alternative fuels on the targeted maritime route

\begin{tabular}{||l|c|c|c|c|c||}
\hline \multicolumn{2}{||}{ Unit price [€/kWh] } & Total fuel price [€/y] & $\begin{array}{c}\text { External costs } \\
{[\text { average scenario] }(€ / \mathrm{y})}\end{array}$ & Fuel price & External costs \\
\cline { 5 - 7 } & & & $761,840.7$ & \multicolumn{2}{c||}{$/$} \\
\hline Euro Diesel** & 0,21 & $8,412,644.7 \times 0,21=1,766,655.4$ & $451,870.1$ & 76.19 & 40.69 \\
\hline Electric & 0,05 & $8,412,644.7 \times 0,05=420,632.2$ & $658,143.0$ & 80.95 & 13.61 \\
\hline
\end{tabular}

*LNG SFOC $170 \mathrm{~g} / \mathrm{kWh}$

**Euro Diesel SFOC $208 \mathrm{~g} / \mathrm{kWh}$

Source: [65-67] 
LNG. Despite greater cost savings in the fuel price by switching from Euro Diesel to LNG, external cost savings are almost three times higher when utilizing electric power on ro-ro ferries due to significantly lower $\mathrm{CO}_{2}$ emissions. It confirms the utmost importance of $\mathrm{CO}_{2}$ emissions, which as an external cost structural element, dominates overall emissions and has greater social significance. Also, by taking into consideration the economic perspective, it should be noted that the estimated net profit of a shipping company operating on the examined ro-ro ferry route was around $€ 2$ million in 2019 [68] while the annual income reached $€ 5.5$ million [69]. If the assumed duration of the concession for the long-term use of the coast in the area of Kamenari and Lepetane was provided for a period of 15 years, where the net profit of around $€ 30$ million is expected [69], the potential conversion to more ecologically acceptable fuel is justified.

This research was the first attempt to compare the generated emissions and indicate the potential savings of the fuel switch between the selected propulsions on the Kamenari-Lepetane ro-ro ferry route. However, some limitations should be noted. The authors calculated only the exhaust emissions as the most dominant component of the overall external costs, while the remaining segments were left neglected, primarily due to the lack of relevant data. Particular data used in the calculation was assessed rather than presented as the real values, as a consequence of limited available data. Also, as already mentioned, the investments in the retrofit of the propulsion systems have not been integrated into the model. Recommendations for future research include calculation and integration of the remaining external cost components to determine the overall impact of the commercial activity on the environment and society. Furthermore, a comprehensive study would enable an external costs comparison of the selected ro-ro ferry route with the road component in the Bay of Kotor. These research findings would enable the authors to determine an ecologically more acceptable transport mode from the external cost standpoint.

\section{CONCLUSION}

The ro-ro ferry route Kamenari-Lepetane was selected to perform external cost calculation and comparison of four different fuel type combustion systems. All the available transport alternatives generally include the increase of environmental degradation, such as the use of road transport around and construction of the bridge over the Bay of Kotor. In the conditions of the complete internalization of the external costs and by following the recent global environmental incentives and regulations, electric power is indicated as ecologically more acceptable in all examined scenarios. The results show lower levels of $\mathrm{SO}_{\mathrm{x}}$, $\mathrm{NO}_{\mathrm{x}}, \mathrm{PM} 2.5, \mathrm{PM} 10$, and $\mathrm{CO}_{2}$ emissions compared to the use of LS MGO, Euro Diesel, and LNG fuel. Switching from other examined fuel types to electric power, the valorization of emissions expressed in monetary values resulted in cost savings. At the average level, it amounted to $573,866.9 € / \mathrm{y}$ compared to the use of LS MGO, 309,970.6 $€ / y$ when switching from Euro Diesel fuel, and 206,272.9€/y compared to the use of LNG. By adding the fuel costs savings of the use of LNG and electric power, the benefits and potential conversion to "greener" technologies is gaining empirical foundation. The possibility of funding the conversion of the fuel type change on ro-ro ferries from the generated net profit of the concessionaire on the examined maritime route confirms the sustainability of the investment. Also, the share of the impact of pollutant emissions on human health is significantly lower with the use of LNG and electricity, which illustrates the benefits of using alternative fuels. The recommendations for further research on the examined ro-ro ferry route include the calculation of costs related to the conversion or retrofit of the propulsion system on ro-ro ferries. The costs of investments in shore-side infrastructure providing electrical power or construction of an LNG bunker station should also be explored, as well as the remaining external cost categories.

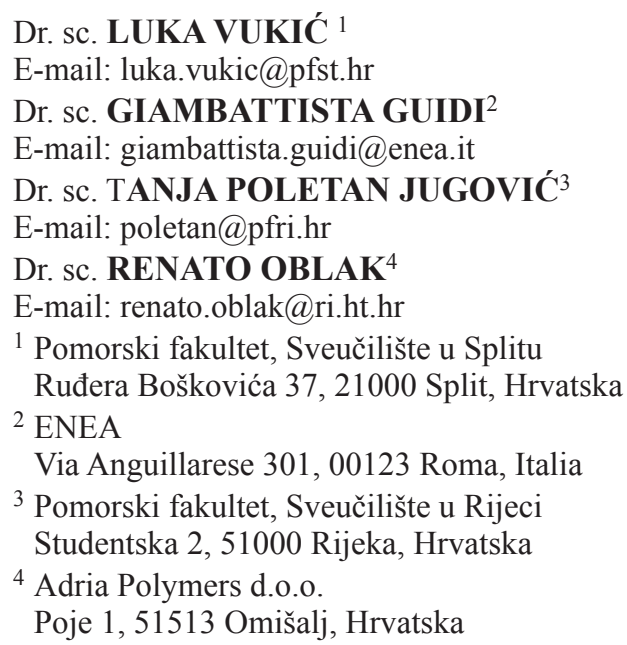




\section{KOMPARACIJA EKSTERNIH TROŠKOVA DIESEL, LNG I ELEKTRIČNE PROPULZIJE NA RO-RO TRAJEKTNOJ LINIJI}

\section{SA ŽETAK}

Slijedom održive prometne politike, ekološki kriteriji postaju sve veći čimbenik konkurentnosti u pomorskoj industriji. Korištenje ,zelenih goriva“ $u$ motorima $s$ unutarnjim izgaranjem, uključujući i električni pogon, mjera je koja može reducirati eksterne troškove prijevoza. Alternativna goriva u pomorskom prometu, koristi $i$ potencijalne uštede analizirane su na primjeru $R O-R O$ trajektne rute Kamenari-Lepatane u Boki Kotorskoj. Rezultati ukazuju na veće ukupne uštede troškova goriva prelaskom na LNG pogon, u komparaciji s električnim pogonom. Međutim, eksterni troškovi potonjeg znatno su niži, posebice u slučaju ako se u procesu proizvodnje koriste obnovljivi izvori energije, naspram korištenja fosilnih goriva. Dobiveni rezultati, u odnosu na veličinu $i$ pretpostavljenu potpunu internalizaciju eksternih troškova, opravdavaju poticaj za korištenje obnovljivih izvora energije na ispitivanoj RO-RO trajektnoj ruti. Kriteriji zaštite okoliša trebali bi igrati odlučujuću ulogu u procjeni vrijednosti ukupne koristi, prema trenutnim trendovima i propisima o smanjenju emisija u pomorskom prometu.

\section{KLJUČNE RIJEČI}

alternativna goriva; Boka Kotorska; eksterni troškovi; RO-RO trajektna linija; održivi razvoj.

\section{REFERENCES}

[1] Dragović B, Tzannatos E, Tselentis V, Meštrović R, Škurić M. Ship emissions and their externalities in cruise port. Transportation Research Part D: Transport and Environment. 2018;61: 289-300. DOI: 10.1016/j. trd.2015.11.007 [Accessed 15th September 2019].

[2] United Nations Conference on Trade and Development. Review of Maritime Transport 2019. New York, USA: United Nations Publications; 2019. Available from: https://unctad.org/en/PublicationsLibrary/rmt2019_ en.pdf [Accessed 5th September 2019].

[3] Mortensen NB. Ship fuel efficiency in a historical perspective. BIMCO Bulletin. 2009;104(1): 38-46. Available from: https://www.bimco.org/about-us-and-our-members/ publications/bimco-bulletin [Accessed 10th September 2019].

[4] Sames PC, Köpke M. $\mathrm{CO}_{2}$ Emissions of the Container World Fleet. Procedia - Social and Behavioral Sciences. 2012;48: 1-11. DOI: 10.1016/j.sbspro.2012.06.982 [Accessed 15th September 2019].

[5] Merchan AL, Léonard A, Limbourg S, Mostert M. Life cycle externalities versus external costs: The case of inland freight transport in Belgium. Transportation Research Part D: Transport and Environment. 2019;67: 576-595. DOI: 10.1016/j.trd.2019.01.017 [Accessed 15th September 2019].

[6] Chatzinikolaou SD, Oikonomou SD, Ventikos NP. Health externalities of ship air pollution at port - Piraeus port case study. Transportation Research Part D: Transport and Environment. 2015;40: 155-165. DOI: 10.1016/ j.trd.2015.08.010 [Accessed 25th September 2019].

[7] Tzannatos E. Ship emissions and their externalities for Greece. Atmospheric Environment. 2009;44: 2194-2202. DOI: 10.1016/j.atmosenv.2010.03.018 [Accessed 10th September 2019].

[8] Cullinane K, Bergqvist R. Emission control areas and their impact on maritime transport. Transportation Research Part D: Transport and Environment. 2014;28: 1-5. DOI: 10.1016/j.trd.2013.12.004 [Accessed 10th September 2019].

[9] Tzannatos E, Nikitakos N. Natural gas as a fuel alternative for sustainable domestic passenger shipping in Greece. International Journal of Sustainable Energy. 2013;32(6): 724-734. DOI: 10.1080/14786451.2013.811414 [Accessed 10th September 2019].

[10] Hua J, Wu Y, Chen H. Alternative fuel for sustainable shipping across the Taiwan Strait. Transportation Research Part D: Transport and Environment. 2017;52: 254-276. DOI: 10.1016/j.trd.2017.03.015 [Accessed 25th September 2019].

[11] European Commission (EC). Roadmap to a Single European Transport Area - Towards a competitive and resource efficient transport system. White Paper. Brussels, EU: European Commission; 2011. Available from: https://eur-lex.europa.eu/LexUriServ/LexUriServ. do?uri=COM:2011:0144:FIN:EN:PDF [Accessed 20th September 2019].

[12] United Nations Framework Convention on Climate Change (UNFCCC). Report of the Conference of the Parties on its twenty-first session, held in Paris from 30 November to 13 December 201, Part two: Action taken by the Conference of the Parties at its twenty-first session. New York, USA: United Nations; 2015. Available from: https://unfccc.int/resource/docs/2015/cop21/eng/10a01.pdf [Accessed 10th October 2019].

[13] United Nations (UN). Special edition: progress towards the Sustainable Development Goals. New York, USA: United Nations; 2019. Available from: https:// www.un.org/ga/search/view_doc.asp?symbol=A/ RES/70/1\&Lang=E [Accessed 10th October 2019].

[14] European Commission (EC). Transport emissions: Reducing emissions from the shipping sector. Available from: https://ec.europa.eu/clima/policies/transport/shipping_en\#tab-0-1 [Accessed 10th October 2019].

[15] European Commission (EC). Regulation (EU) 2015/757 of the European Parliament and of the Council of 29 April 2015 on the monitoring, reporting and verification of carbon dioxide emissions from maritime transport, and amending Directive 2009/16/EC. Brussels, EU: European Commission; 2016. Available from: https:// eur-lex.europa.eu/legal-content/EN/TXT/PDF/?uri= CELEX:02015R0757-20161216\&from=EN [Accessed 10th October 2019].

[16] Bozicevic Vrhovcak M, Tomsic Z, Debrecin N. External 
costs of electricity production: case study Croatia. Energy Policy. 2005;33: 1385-1395. DOI: 10.1016/j.enpol.2003.12.015 [Accessed 5th October 2019].

[17] Hall DR. Conceptualising tourism transport: Inequality and externality issues. Journal of Transport Geography. 1999;7(3): 181-188. DOI: 10.1016/S09666923(99)00001-0 [Accessed 5th October 2019].

[18] Jin J, Rafferty P. Externalities of auto traffic congestion growth: Evidence from the residential property values in the US Great Lakes megaregion. Journal of Transport Geography. 2018;70: 131-140. DOI: 10.1016/j.jtrangeo.2018.05.022 [Accessed 5th October 2019].

[19] Fridell E, Belhaj M, Wolf C, Jerksjö M. Calculation of external costs for freight transport. Transportation Planning and Technology. 2011;34(5): 413-432. DOI: 10.1080/03081060.2011.586112 [Accessed 10th October 2019].

[20] De Vos J, Witlox F. Transportation policy as spatial planning tool; reducing urban sprawl by increasing travel costs and clustering infrastructure and public transportation. Journal of Transport Geography. 2013;33: 117125. DOI: 10.1016/j.jtrangeo.2013.09.014 [Accessed 15th October 2019].

[21] Song Y, Miller HJ, Stempihar J, Zhou X. Green accessibility: Estimating the environmental costs of network-time prisms for sustainable transportation planning. Journal of Transport Geography. 2017;64: 109-119. DOI: 10.1016/j.jtrangeo.2017.08.008 [Accessed 15th October 2019].

[22] Himanen V, Lee-Gosselin M, Perrels A. Sustainability and the interactions between external effects of transport. Journal of Transport Geography. 2005;13(1): 2328. DOI: 10.1016/j.jtrangeo.2004.11.006 [Accessed 10th October 2019].

[23] Mandić M, Regner S, Gačić Z, Đurović M, Marković O, Ikica Z. Composition and diversity of ichthyoplankton in the Boka Kotorska Bay (South Adriatic Sea). Acta Adriatica. 2014;55(2): 229-244. Available from: http:// jadran.izor.hr/acta/pdf/55_2_pdf/55_2_9.pdf [Accessed 20th October 2019].

[24] Loo BPY, Banister D. Decoupling transport from economic growth: Extending the debate to include environmental and social externalities. Journal of Transport Geography. 2016;57: 134-144. DOI: 10.1016/j.jtrangeo.2016.10.006 [Accessed 25th October 2019].

[25] Nikolić A, Nikolić E. Controlling risk due to noise on ferry boat. Promet - Traffic \& Transportation. 2013;25(4): 387-394. DOI: 10.7307/ptt.v25i4.305 [Accessed 20th October 2019].

[26] Nikolić A, Nikolić D, Nikolić E, Vujačić V. Urban Noise Modelling in Boka Kotorska Bay. Promet - Traffic \& Transportation. 2014;26(2): 151-157. DOI: 10.7307/ptt. v26i2.1331 [Accessed 20th October 2019].

[27] Nikolić D, Gagić R, Ivošević Š. Estimation of Air Pollution from Ships in the Boka Kotorska Bay. In: Joksimović A, Djurović M, Semenov A, Zonn I, Kostianoy A. (eds.) The Boka Kotorska Bay Environment. The Handbook of Environmental Chemistry. Switzerland: Springer, Cham; 2016. p. 117-128.
[28] Van Essen H, Van Wijngaarden L, Schroten A, De Bruyn S, Sutter D, Bieler C, Maffii S, Brambilla M, Fiorello $\mathrm{D}$, Fermi F, Parolin R, El Beyrouty K. Handbook on the external costs of transport. Delft, The Netherlands: CE Delft; 2019

[29] Schreyer C, Maibach M, Rothengarter W, Doll C, Schneider C, Schmedding D. External costs of transport: Update study. Karlsruhe/Zürich/Paris: INFRAS/IWW The International Union of Railways (UIC); 2004.

[30] Maibach M, Schreyer C, Sutter D, Van Essen HP, Boon BH, Smokers R, Schroten A, Doll C, Pawlowska B, Bak M. Handbook on estimation of external costs in the transport sector - IMPACT D1 Version 1.1. Delft, The Netherlands: INFRAS, Report Delft; 2008.

[31] Korzhenevych A, Dehnen N, Bröcker J, Holtkamp M, Meier H, Gibson G, Varma A, Cox V. Update of the Handbook on External Costs of Transport. Final report for European Commission. Oxfordshire, UK: RICARDO-AEA; 2014.

[32] Kalli J, Saikku R, Repka S, Tapaninen U. Maritime traffic externalities in the Gulf of Finland until 2030. Transport. 2012;27(1): 92-101. DOI: 10.3846/16484142.2012.668497 [Accessed 20th October 2019].

[33] Yang X, Li H, Wallin F, Wang Z. Impacts of Emission Reduction Target and External Costs on Provincial Natural Gas Distribution in China. Energy Procedia. 2017;105: 3326-3331. DOI: 10.1016/j.egypro.2017.03.760 [Accessed 25th October 2019].

[34] Lowell D, Wang H, Lutsey N. Assessment of the fuel cycle impact of liquefied natural gas as used in international shipping. Washington DC, USA: The International Council on Clean Transportation; 2013.

[35] Järvi A. Methane slip reduction in Wärtsilä lean burn gas engines. In: Proceedings on the $26^{\text {th }}$ CIMAC World Congress on Combustion Engines, 14-17 June 2010, Bergen, Norway. Bergen: CIMAC; 2010. p. 106.

[36] Laugen L. 2013. An environmental life cycle assessment of LNG and HFO as marine fuels. Master thesis. Norwegian University of Science and Technology; 2013.

[37] Wang S, Notteboom T. The perspectives and challenges of LNG as a ship fuel: Conducting a systematic review and research syntheses. In: IAME 2013: Conference Proceedings, 3-5 July 2013, Marseille, France. Marseille, France: IAME; 2013. p. 37-41.

[38] Acciaro M. Real option analysis for environmental compliance: LNG and emission control areas. Transportation Research Part D: Transport and Environment. 2014;28: 41-50. DOI: 10.1016/j.trd.2013.12.007 [Accessed 25th October 2019].

[39] Farrell A, Glick M. Natural Gas as a Marine Propulsion Fuel: Energy and Environmental Benefits in Urban Service Ferries. Transportation Research Record Journal of the Transportation Research Board. 2007;1738: 7785. Available from: https://journals.sagepub.com/doi/ abs/10.3141/1738-09 [Accessed 15th October 2019].

[40] JTC (Joint Transportation Committee). Evaluating the Use of Liquefied Natural Gas in Washington State Ferries. Olympia, USA: Joint Transportation Committee; 
Vukić L, et al. Comparison of External Costs of Diesel, LNG, and Electric Drive on a Ro-Ro Ferry Route

2012. Available from: http://www.leg.wa.gov/JTC/Documents/Studies/LNG/LNG_FINALReport_Jan2012.pdf [Accessed 25th October 2019].

[41] Livanos GA, Theotokatos G, Pagonis DN. Techno-economic investigation of alternative propulsion plants for Ferries and RoRo ships. Energy Conversion and Management. 2014;79: 640-651. DOI: 10.1016/j.enconman.2013.12.050 [Accessed 25th October 2019].

[42] Eise Fokkema J, Buijs P, Vis IFA. An investment appraisal method to compare LNG-fueled and conventional vessels. Transportation Research Part D: Transport and Environment. 2017;56: 229-240. DOI: 10.1016/j. trd.2017.07.021 [Accessed 25th October 2019].

[43] DNV GL. Industry insights, Leading the charge. Available from: https://www.dnvgl.com/expert-story/maritime-impact/leading-the-charge.html [Accessed 25th October 2019].

[44] Zis T, North RJ, Angeloudis P, Ochieng WY, Bell MGH. Evaluation of cold ironing and speed reduction policies to reduce ship emissions near and at ports. Maritime Economics \& Logistics. 2014;16(4): 371-398. DOI: 10.1057/ mel.2014.6 [Accessed 25th October 2019].

[45] Innes A, Monios J. Identifying the unique challenges of installing cold ironing at small and medium ports The case of Aberdeen. Transportation Research Part D: Transport and Environment. 2018;62: 298-313. DOI: 10.1016/j.trd.2018.02.004 [Accessed 25th October 2019].

[46] Bianucci M, Merlino S, Ferrando M, Baruzzo L. The optimal hybrid/electric ferry for the Liguria Natural Parks. OCEANS 2015 - Genova IEEE. 2015;1: 1-10. DOI: 10.1109/OCEANS-Genova.2015.7271474 [Accessed 25th October 2019].

[47] Sciberras EA, Zahawi B, Atkinson DJ. Reducing shipboard emissions - Assessment of the role of electrical technologies. Transportation Research Part D: Transport and Environment. 2017;51: 227-239. DOI: 10.1016/j. trd.2016.10.026 [Accessed 25th October 2019].

[48] Davarzani H, Fahimnia B, Bell M, Sarkis J. Greening ports and maritime logistics: A review. Transportation Research Part D: Transport and Environment. 2016;48: 473-487. DOI: 10.1016/j.trd.2015.07.007 [Accessed 25th October 2019].

[49] Stensvold T. Batterikreftene slår seg sammen: - Nå går det fort. Available from https://www.tu.no/artikler/batterikreftene-slar-seg-sammen-na-gar-det-fort/276225 [Accessed 30th October 2019].

[50] Mutarraf M, Terriche Y, Niazi K, Vasquez J, Guerrero J. Energy Storage Systems for Shipboard Microgrids - A Review. Energies. 2018;11(12): 3492. DOI: 10.3390/ en11123492 [Accessed 25th October 2019].

[51] Sandell J, Segerlind J. Ship propulsion using wind, batteries and diesel-electric machinery - Dimensioning of a propulsion system using wind, batteries and diesel-electric machinery. Student thesis. Chalmers University of Technology, Sweden; 2016.

[52] AEVA (2019) Electric Vehicle News Issue 237. Available from: https://www.aeva.asn.au/sites/default/files/public/ u28/AEVA\%20EVNews\%20237-Hi\%20Res.pdf [Ac- cessed 15th November 2019].

[53] Gagatsi E, Estrup T, Halatsis A. Exploring the Potentials of Electrical Waterborne Transport in Europe: The E-ferry Concept. Transportation Research Procedia. 2016;14: 1571-1580. DOI: 10.1016/j.trpro.2016.05.122 [Accessed 30th October 2019].

[54] Yiğit K, Acarkan B. A new ship energy management algorithm to the smart electricity grid system. International Journal of Energy Research. 2018;42(8): 2741-2756. DOI: 10.1002/er.4062 [Accessed 30th October 2019].

[55] Ballini F, Bozzo R. Air pollution from ships in ports: The socio-economic benefit of cold-ironing technology. Research in Transportation Business \& Management. 2015;17: 92-98. DOI: 10.1016/j.rtbm.2015.10.007

[56] UNESCO World Heritage Center. Natural and Culturo-Historical Region of Kotor (Montenegro). Available from: https://whc.unesco.org/en/soc/265 [Accessed 25th November 2019].

[57] Pomorski saobraćaj. Timetable. Available from: http:// www.ferry.co.me/RedVoznje.html [Accessed 25th November 2019]

[58] Cummins Marine. Interactive product guide 16/07/2001. USA: Division of Cummins Inc., Bulletin; 2001. Available from: www.cummins.com [Accessed 5th December 2019].

[59] CE Delft. Stream Freight transport 2016: Emissions of freight transport modes. Delft, The Netherlands: CR Delft publications; 2016. Available from: https:// www.cedelft.eu/publicatie/stream_freight_transport_2016/1855 [Accessed 10th December 2019].

[60] Statistics Norway. Emission factors used in the estimations of emissions from combustion. Available from: https://www.ssb.no/_attachment/291696/binary/95503?_version=547186 [Accessed 5th December 2019].

[61] Viana M, Hammingh P, Colette A, Querol X, Degraeuwe B, de Vlieger I, van Aardenne J. Impact of maritime transport emissions on coastal air quality in Europe. Atmospheric Environment. 2104;90: 96-105. DOI: 10.1016/ j.atmosenv.2014.03.046 [Accessed 10th December 2019].

[62] Ančić I. Energy efficiency and environmental impact of marine integrated power systems. Doctoral thesis. Faculty of Mechanical Engineering and Naval Architecture, University of Zagreb; 2016.

[63] Servis Perković. Financial comparison of energy products with respect to fuel energy value and utilization. Available from: http://www.servis-perkovic.hr/ financijska-usporedba-energenata [Accessed 15th December 2019].

[64] World Bank. Western Balkans: Directions for the Energy Sectors. Available from: http://documents.worldbank.org/curated/en/201391544823541838/pdf/Western-Balkans-Energy-Directions-Paper.pdf [Accessed 15th December 2019].

[65] Eurostat. Natural Gas Price Statistics. Available from: https://ec.europa.eu/eurostat/statistics-explained/index. php/Natural_gas_price_statistics [Accessed 15th December 2019].

[66] EPCG. Household prices. Available from: https://www. 
epcg.com/domacinstva/tarife [Accessed 15th December 2019].

[67] Bankar. Fuel prices in Montenegro. Available from: https://www.bankar.me/tag/cijene-goriva-u-crnoj-gori/ [Accessed 20th December 2019].

[68] Pomorac. Trajekt Kamenari-Lepetane donio profit od 1,95 milijuna. Available from: http://pomorac.net/2019/04/11/ trajekt-kamenari-lepetane-donio-profit-od-195-milijuna/ [Accessed 20th December 2019].

[69] Investitor. Tko će dobiti trajektnu liniju Kamenari - Lepetane i neto dobit od najmanje 30 miliona eura. Available from: https://investitor.me/2019/02/04/ko-ce-dobiti-trajektnu-liniju-kamenari-lepetane-i-neto-dobit-od-najmanje-30-miliona-eura/ [Accessed 20th December 2019]. 